\title{
Estimation of the feeding record of pregnant Antarctic minke whales (Balaenoptera bonaerensis) using carbon and nitrogen stable isotope analysis of baleen plates
}

\author{
Mayuka Uchida ${ }^{1}$ Ippei Suzuki ${ }^{2,3}$ (1) $\cdot$ Keizo Ito $^{1,4} \cdot$ Mayumi Ishizuka $^{5} \cdot$ Yoshinori Ikenaka $^{5,6} \cdot$ Shouta M. M. Nakayama $^{5}$. \\ Tsutomu Tamura $^{7} \cdot$ Kenji Konishi $^{7} \cdot$ Takeharu Bando $^{7} \cdot$ Yoko Mitani $^{2}$
}

Received: 4 March 2020 / Revised: 22 January 2021 / Accepted: 27 January 2021 / Published online: 22 February 2021

(c) The Author(s) 2021

\begin{abstract}
Antarctic minke whales (Balaenoptera bonaerensis) are migratory capital breeders that experience intensive summer feeding on Antarctic krill (Euphausia superba) in the Southern Ocean and winter breeding at lower latitudes, but their prey outside of the Antarctic is unknown. Stable isotope analyses were conducted on $\delta^{13} \mathrm{C}$ and $\delta^{15} \mathrm{~N}$ from the baleen plates of ten pregnant Antarctic minke whales to understand the growth rate of the baleen plate and their diet in lower latitudes. Two to three oscillations along the length of the edge of the baleen plate were observed in $\delta^{15} \mathrm{~N}$, and the annual growth rate was estimated to be $75.2 \pm 20.4 \mathrm{~mm}$, with a small amplitude $(0.97 \pm 0.21 \%$ ). Bayesian stable isotope mixing models were used to understand the dominant prey that contributed to the isotopic component of the baleen plate using Antarctic krill from the stomach contents and reported values of Antarctic coastal krill (Euphausia crystallorophias), Antarctic silver fish (Pleuragramma antarcticum), Australian krill spp., and Australian pelagic fish spp.. The models showed that the diet composition of the most recent three records from the base of the baleen plates (model 1) and the highest $\delta^{15} \mathrm{~N}$ values in each baleen plate (model 2) were predominantly Antarctic krill, with a contribution rate of approximately $80 \%$. The rates were approximately $10 \%$ for Antarctic coastal krill and less than 2.0\% for the two Australian prey groups in both models. These results suggest that pregnant Antarctic minke whales did not feed on enough prey outside of the Antarctic to change the stable isotope values in their baleen plates.
\end{abstract}

Keywords Feeding record $\cdot$ Stable isotope analysis $\cdot$ Baleen plate $\cdot$ Antarctic minke whales $\cdot$ Antarctic

\section{Introduction}

The research reported here involved lethal sampling of minke whales, which was based on a permit issued by the Japanese Government in terms of Article VIII of the International Convention for the Regulation of Whaling. Reasons for the scientific need for this sampling have been stated both by the Japanese Government and by the authors.

Ippei Suzuki

ippszk@gmail.com

1 Graduate School of Environmental Science, Hokkaido University, Hakodate, Japan

2 Field Science Center for Northern Biosphere, Hokkaido University, Hakodate, Japan

3 Present Address: Akkeshi Marine Station, Field Science Center for Northern Biosphere, Hokkaido University, Akkeshi, Japan
The Antarctic minke whale (Balaenoptera bonaerensis) is a small rorqual that migrates to its feeding ground in the Southern Ocean during the summer. Their prey here is known to be Antarctic krill (Euphausia superba) based on stomach content analyses (Ichii and Kato 1991; Tamura and

4 Sarufutsu Fishery Cooperative Association, Sarufutsu, Japan

5 Faculty of Veterinary Medicine, Hokkaido University, Sapporo, Japan

6 Water Research Group, Unit for Environmental Science and Management, North-West University, Potchefstroom, South Africa

7 Institute of Cetacean Research, Tokyo, Japan 
Konishi 2009). During winter, these animals are thought to migrate to lower latitudes for breeding (Kasamatsu et al. 1995). A report of a marlin spear found in the jaw of an Antarctic minke whale supports this theory (Ohsumi 1973). According to Japanese sighting surveys from 1976 to 1987, mature whales and pregnant females departed their breeding areas by November, and the majority had migrated to the Southern Ocean by January (Kasamatsu et al. 1995). However, their mating behavior has not been observed, and their breeding areas are not currently understood. According to an ear plug analysis, the gestation period in Antarctic minke whales is approximately 10 months (Ohsumi and Masaki 1975; Lockyer 1984; Kato 1990), and Best (1982) estimated a yearly reproductive rate of $78.4 \%$. Both the numbers of animals recruited from the young generation to the reproductive population and those leaving the reproductive population due to either death or over aging are unknown or limited. Moreover, the inter-reproductive cycle of this species is not yet understood comprehensively, which means that the number of pregnant individuals migrating lower latitudes every year remains unclear, though pregnant females do need to migrate to breeding areas. This is likely important for newborns without adequate adipose tissue to survive in the cold Antarctic environment. However, knowledge of Antarctic minke whale feeding behavior outside of the Southern Ocean is limited, as most research on this species has been conducted in the Southern Ocean during summer.

Feeding records of baleen whales can be estimated by measuring the stable carbon $\left(\delta^{13} \mathrm{C}\right)$ and nitrogen $\left(\delta^{15} \mathrm{~N}\right)$ isotope compositions of their baleen plates (Schell et al. 1989). Large oscillations of $\delta^{13} \mathrm{C}$ along the length of the baleen plates in bowhead whales (Balaena mysticetus) correlated with geographic variation in zooplankton $\delta^{13} \mathrm{C}$ with an amplitude of 2-3\%o, revealing when and where bowhead whales foraged (Schell et al. 1989). Baleen plates are metabolically inert after formation; therefore, isotopic changes along the baleen length can provide a foraging record if the growth rate of baleen plates is predictable. In general, most baleen whales are migratory over a geographically large scale. This enables the growth rate of baleen plates to be predicted, as one cycle of the oscillation in $\delta^{13} \mathrm{C}$ and $\delta^{15} \mathrm{~N}$ takes approximately one year. The baleen plate of the common minke whale (Balaenoptera acutorostrata), for example, preserves a foraging record of approximately 1.4 years, based on an estimated annual growth rate of $129 \mathrm{~mm}$ (Mitani et al. 2006). Additionally, the comparison of the isotopic composition between whales and their prey enabled the estimation of prey shifts during migration in common minke whales and humpback whales (Megaptera novaeangliae) (Mitani et al. 2006; Eisenmann et al. 2016), and individual differences in $\delta^{15} \mathrm{~N}$ records suggest diverse feeding strategies in the sei whales (Balaenoptera borealis) depending on migratory routes (Reiss et al. 2020).
The effects of physiological changes, such as fasting and pregnancy, on stable isotope values in baleen whales have been examined in previous studies, but a clear understanding has not yet been established. In bowhead whales, for example, a study on the stable isotope values of muscle tissues indicated increased $\delta^{15} \mathrm{~N}$ values as an effect of the period of fasting (or 'near-fasting') (Lee et al. 2005), and another study on the baleen plates of southern right whales (Eubalaena australis) indicated that the period of fasting did not have an impact on stable isotope values (Best and Schell 1996). On the other hand, a stable isotope study of the muscle tissues and baleen plates of fin whales (Balaenoptera physalus) found decreased $\delta^{15} \mathrm{~N}$ values during migration periods as an effect of fasting (Aguilar et al. 2014). This was not consistent with the widely accepted increase in $\delta^{15} \mathrm{~N}$ values in terrestrial vertebrates during fasting periods due to the loss of the lighter isotope $\left({ }^{14} \mathrm{~N}\right)$ for protein catabolism (Hobson et al. 1993; Polischuck et al. 2001; Fuller et al. 2005). In addition, the effects of pregnancy on stable isotopes in humpback whales have been proposed in a previous study (Clark et al. 2016), and decreases in both $\delta^{13} \mathrm{C}$ and $\delta^{15} \mathrm{~N}$ values were expected because of increased lipid metabolism to support the energetic costs of early pregnancy and the reduction of nitrogen excretion. Although decreases in both $\delta^{13} \mathrm{C}$ and $\delta^{15} \mathrm{~N}$ were observed in the first year, this theoretical prediction was not statistically confirmed by blubber tissue samples from the two-year experiment.

Changes in the isotopic compositions from baleen plates could reveal the foraging and migration habits of Antarctic minke whales outside of the Southern Ocean. In this study, we performed a stable isotope analysis on the baleen plates of pregnant Antarctic minke whales to (1) compare the stable isotope values between the base of the baleen plate and Antarctic krill from the stomach contents of the whales, (2) estimate the growth rate and recording period of the baleen plate in Antarctic minke whales, and (3) identify the dominant prey during the breeding season using reported stable isotope values for Antarctic coastal krill (E. crystallorophias), Antarctic silverfish (Pleuragramma antarcticum), a group of Australian krill spp., and a group of Australian pelagic fish spp. in addition to the measured stable isotope values of Antarctic krill obtained from the Antarctic minke whales' stomach contents in this study. In addition, the effects of physiological changes, fasting, and pregnancy on the stable isotopes of the baleen plates were examined, as all individuals were expected to experience migration to lower latitudes for breeding, which could be potential fasting periods, and all were pregnant. 


\section{Materials and methods}

The baleen plates used in this study were collected from the Japanese research whaling conducted during the 2015/16 season (New Scientific Whale Research Program in the Antarctic Ocean: NEWREP-A). The baleen plates were obtained from ten pregnant female Antarctic minke whales (body length: $8.88 \pm 0.33 \mathrm{~m}$, mean $\pm \mathrm{SD}$ ) in the Ross Sea and preserved at $-20{ }^{\circ} \mathrm{C}$. Morphological measurements of the body length, blubber thickness, and baleen length were collected (Table 1). The stomach contents were analyzed to reveal their recent prey, except for one individual (ID No. AM085), as the stomach was damaged by a harpoon.

The frozen baleen plates were placed at room temperature. After defrosting, the remaining gum on the plates was removed with commercially available steel wool. The longest edge of each cleaned plate was cut into $10 \mathrm{~mm}$ widths and divided every $5 \mathrm{~mm}$ from the base. Each $5 \mathrm{~mm}$ section was numbered and only odd numbers were used as samples. Each sample was placed in a $3 \mathrm{ml}$ vial container with a 2:1 chloroform-methanol mixed solution for $24 \mathrm{~h}$ to remove the lipid content. The delipidated samples were dried at $60{ }^{\circ} \mathrm{C}$ for $48 \mathrm{~h}$, and each dried sample was reduced to a powder using a drill (DREMEL Battery mini rooter MICRO, $\mathrm{BOSCH}$, Stuttgart, Germany). Approximately $0.6 \mathrm{mg}$ of the powdered samples were placed in a tin capsule and into a mass spectrometer (IsoPrime100, IsoPrime, Stockport, United Kingdom) connected to an elemental analyzer (vario MICRO cube, Elementar, Langenselbold, Germany). These analyses were performed at the Graduate School of Veterinary Medicine, Hokkaido University (Sapporo, Japan).

The stable isotope ratios were expressed in delta $(\delta)$, and the relative variations of the stable isotope ratios were expressed as permil $(\% o)$ deviations from the predetermined international standard by the following equation:

$\delta X=\left[\left(R_{\text {sample }} / R_{\text {standard }}\right)-1\right] \times 1000$,

Table 1 Contribution rates of potential prey species (Antarctic krill (Euphausia superba), Antarctic coastal krill (Euphausia crystallorophias), and Antarctic silver fish (Pleuragramma antarcticum), a group of Australian krill spp., and a group of Australian pelagic fish where $X$ is either ${ }^{13} \mathrm{C}$ or ${ }^{15} \mathrm{~N}$. $R_{\text {sample }} / R_{\text {standard }}$ is either the ${ }^{13} \mathrm{C} /{ }^{12} \mathrm{C}$ or ${ }^{15} \mathrm{~N} /{ }^{14} \mathrm{~N}$ ratio of the sample and standard, respectively. The standards used were Vienna Pee Dee Belemnite (V-PDB) calcium carbonate for ${ }^{13} \mathrm{C}$, and ambient atmospheric nitrogen for ${ }^{15} \mathrm{~N}$. Based on the analysis of the replicate standards, the standard deviation for $\delta^{13} \mathrm{C}$ and $\delta^{15} \mathrm{~N}$ averaged $0.19 \%$ and $0.09 \%$, respectively.

The stable isotope values of five potential prey species (Antarctic krill, Antarctic coastal krill, Antarctic silver fish, a group of Australian krill spp., and a group of Australian pelagic fish spp.) were compared with those of the baleen plates to determine what the whales preyed on during the recorded period. Antarctic krill collected from the stomach contents of Antarctic minke whales during the Japanese Whale Research Program under Special Permit in the Antarctic (JARPA II) were used for this study. The Antarctic krill $(N=2)$ collected from the stomach contents were analyzed by a commercial company (Japan Chemical Analysis Center info Institute of Cetacean Research). Other values of $\delta^{13} \mathrm{C}$ and $\delta^{15} \mathrm{~N}$ were obtained from publications (Antarctic coastal krill $(N=1):-25.3 \%$, 5.1\%o (Hodum and Hobson 2000); Antarctic silver fish: $-25.0 \pm 0.8 \%$ o $10.3 \pm 0.8 \%$ o (Pinkerton et al. 2013), expressed as the mean \pm SD, for $\delta^{13} \mathrm{C}$ and $\delta{ }^{15} \mathrm{~N}$, respectively). The average stable isotope values from two groups of Australian species groups, a group of krill spp. and a group of pelagic fish spp., were obtained by mixing several species of either krill or pelagic fish from previous studies, as any of these species can be potential prey for Southern hemisphere humpback whales (Eisenmann et al. 2016). The Australian krill group contained Thysannessa gregaria and Euphausia similis, and the averaged stable isotope values were $-19.7 \pm 0.4 \%$ o for $\delta^{13} \mathrm{C}$ and $8.3 \pm 0.5 \%$ for $\delta^{15} \mathrm{~N}$ (Harris et al. 2014; Eisenmann et al. 2016). The Australian pelagic fish group included redbait (Emmelichthys nitidis), jack mackerel (Trachurus declivis), Gould's squid (Nototodarus gouldi), barber perch (Caesioperca rasor), Hector's lanternfish (Lampanyctodes hectoris), pennant lightfish (Maurolicus muelleri), blue

spp. to the baleen plates of pregnant Antarctic minke whales (Balaenoptera bonaerensis) calculated by the Bayesian stable isotope mixing model SIAR (Parnell et al. 2010))

\begin{tabular}{|c|c|c|c|c|c|}
\hline Sample point & Antarctic krill & Antarctic coastal krill & Antarctic silver fish & Australian krill spp. & $\begin{array}{l}\text { Australian } \\
\text { pelagic fish } \\
\text { spp. }\end{array}$ \\
\hline $0 \mathrm{~mm}$ & 0.822 & 0.093 & 0.049 & 0.019 & 0.016 \\
\hline $10 \mathrm{~mm}$ & 0.803 & 0.098 & 0.064 & 0.019 & 0.017 \\
\hline $20 \mathrm{~mm}$ & 0.810 & 0.093 & 0.061 & 0.019 & 0.017 \\
\hline Maximum $\delta{ }^{15} \mathrm{~N}$ value & 0.763 & 0.110 & 0.088 & 0.020 & 0.018 \\
\hline
\end{tabular}

The contribution rates were shown for the three most recent samples $\left(0,10,20 \mathrm{~mm}\right.$ from the base of the baleen plate) and the maximum $\delta^{15} \mathrm{~N}$ value in each baleen plate 
warehou (Seriolella brama), and silver warehou (Seriolella punctata), with average calculated stable isotope values of $-18.7 \pm 0.9 \%$ for $\delta^{13} \mathrm{C}$ and $11.8 \pm 0.7 \%$ for $\delta^{15} \mathrm{~N}$ (Davenport and Bax 2002; Eisenmann et al. 2016). The relative whale diet composition of potential prey was determined by the Bayesian stable isotope mixing model, using the Stable Isotope Analysis in R (SIAR) (Parnell et al. 2010). We used two model variants to quantify the contribution rate for each prey species using recent records that are preserved close to the base of the baleen plate (Model 1), and the maximum $\delta^{15} \mathrm{~N}$ values in each baleen plate (Model 2). We used trophic enrichment factors of $2.26 \pm 0.30 \%$ for $\delta^{13} \mathrm{C}$ and $2.77 \pm 0.22 \%$ o for $\delta^{15} \mathrm{~N}$ (mean $\left.\pm \mathrm{SD}\right)$ for the analysis, which are the reported values in fin whales (Borrell et al. 2012). Model 1 used $\delta^{13} \mathrm{C}$ and $\delta^{15} \mathrm{~N}$ from three points $(0,10$, and $20 \mathrm{~mm}$ ) from the base of each baleen plate, and Model 2 used $\delta^{13} \mathrm{C}$ and $\delta^{15} \mathrm{~N}$ from the point with the highest $\delta^{15} \mathrm{~N}$ values in each baleen plate. Both models used five potential prey species to determine the diet composition.

Periodic cycles in $\delta^{15} \mathrm{~N}$ fluctuations are considered to be the annual growth rate of the baleen plate, following the method described in previous studies (Borrell et al. 2012; Aguilar et al. 2014). Two consecutive minimum $\delta^{15} \mathrm{~N}$ points were regarded as the annual growth rate of the baleen plate in this study. The number of cycles in $\delta^{13} \mathrm{C}$ fluctuations was also counted using the method described above. A cycle with less than $20 \mathrm{~mm}$ cycle length was not counted as a single cycle, and the cycle length was measured until two consecutive minimum points became longer than $30 \mathrm{~mm}$.

A correlation analysis was performed with the differential stable isotope values $\left(\delta^{13} \mathrm{C}\right.$ and $\delta^{15} \mathrm{~N}$ ) (which were the difference in $\delta^{13} \mathrm{C}$ or $\delta^{15} \mathrm{~N}$ between each consecutive point every $10 \mathrm{~mm}$ along the baleen plate base) between 0 and $10 \mathrm{~mm}$ and the blubber thickness using Spearman's rank correlation coefficients to examine the effect of pregnancy on the stable isotope values. According to a previous study (Konishi et al. 2008), the blubber thickness was significantly related to the duration of feeding in the Southern Ocean; thus, a longer duration in the Southern Ocean would indicate a more developed stage of pregnancy.

All data are expressed as the mean \pm SD. An SIAR was performed in R software, version 4.0.3 (R Development Core Team), using the package SIAR (Parnell et al. 2010). The Spearman's rank correlation was performed in Excel with BellCurve for Excel version 3.21 (Social Survey Research Information Co., Ltd., Tokyo, Japan).

\section{Results}

The average length of the baleen used in this study was $276 \pm 21 \mathrm{~mm}$ (Online Resource 1a). The average stable isotope values at the base of the baleen were $-25.01 \pm 0.49 \%$ o for $\delta^{13} \mathrm{C}$ and $7.03 \pm 0.33 \%$ for $\delta^{15} \mathrm{~N}$ (Fig. 1, Online

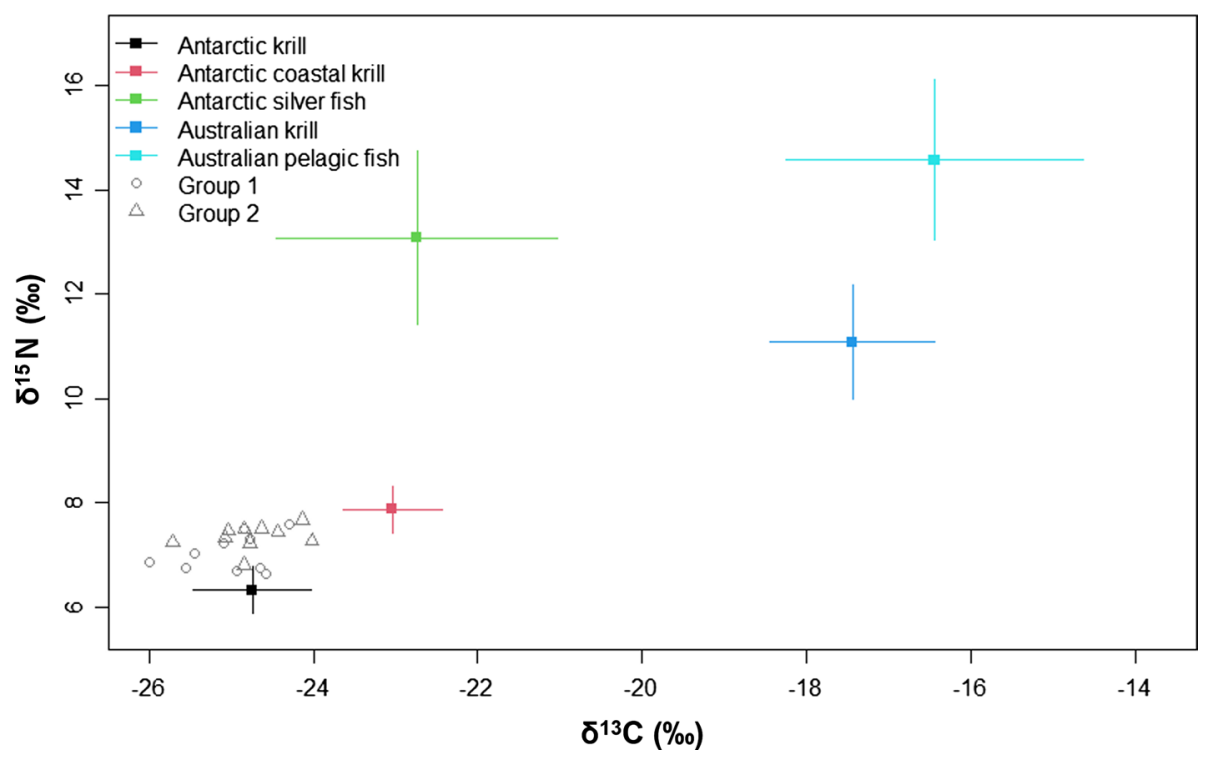

Fig. 1 Comparison of stable isotope values of $\delta^{13} \mathrm{C}$ and $\delta^{15} \mathrm{~N}$ between the baleen plates from pregnant Antarctic minke whales (Balaenoptera bonaerensis) and five possible prey species: Antarctic krill (Euphausia superba, black), Antarctic coastal krill (Euphausia crystallorophias, red), Antarctic silver fish (Pleuragramma antarcticum, green), Australian krill spp. (blue), and Australian pelagic fish spp. (light blue). Group 1 is the isotopic values from the base of the baleen plate and Group 2 is those from the maximum $\delta^{15} \mathrm{~N}$ value in each baleen plate. This biplot was created using Bayesian mixing model SIAR (Parnell et al. 2010). Error bars represent 95\% confidence intervals and incorporate the error in the source isotopic signatures and in trophic enrichment factors $\left(\delta^{13} \mathrm{C}: 2.26 \pm 0.30 \%\right.$ o $\mathrm{SD}, \delta^{15} \mathrm{~N}$ : $2.77 \pm 0.22 \%$ o SD) 
Resource 1a). The average stable isotope values of Antarctic krill were $-27.0 \pm 0.2 \%$ for $\delta^{13} \mathrm{C}$ and $3.6 \pm 0.05$ $\%$ for $\delta^{15} \mathrm{~N}$. Species with both stable isotope values lower than those of the baleen plates were Antarctic krill and Antarctic coastal krill. The difference in the isotope values between the base of the baleen plates and Antarctic krill was $+1.99 \%$ ofor $\delta^{13} \mathrm{C}$ and $+3.48 \%$ or $\delta^{15} \mathrm{~N}$, and for Antarctic coastal krill were $+0.29 \%$ for $\delta^{13} \mathrm{C}$ and $+1.93 \%$ o for $\delta^{15} \mathrm{~N}$.

In Antarctic minke whales, the difference between the maximum and minimum values of $\delta^{15} \mathrm{~N}$ was $0.97 \pm 0.21 \%$ o and $1.08 \pm 0.40 \%$ o for $\delta^{13} \mathrm{C}$ (Fig. 2, Online Resource 1a). The average number of periodic cycles in $\delta^{15} \mathrm{~N}$ was $2.3 \pm 0.5$ (range 2-3 cycles in each baleen plate), and the mean length of a periodic cycle was $75.2 \pm 20.4 \mathrm{~mm}$ (range 50-120 mm), with a maximum length of $120 \mathrm{~mm}$ in one individual (ID No. AM313) (Fig. 2, Online Resource 1b). The average number of cycles in $\delta^{13} \mathrm{C}$ was $2.7 \pm 1.2$ (range $1-4$ cycles in each baleen plate), and the mean length of the cycle was $66.3 \pm 26.5 \mathrm{~mm}$ (range $30-150 \mathrm{~mm}$ ), with a maximum length of $150 \mathrm{~mm}$ in one individual (ID No. AM067) (Fig. 2, Online Resource 1b).

The contribution rates of the baleen plates estimated from the three most recent points (Model 1) were dominated by Antarctic krill, which had mean proportional contribution rates of $82.2 \%, 80.3 \%$, and $81.0 \%$, respectively, from the base of the baleen plates (Table 1, Online Resource 2a). The contribution rates of Antarctic coastal krill and Antarctic silver fish were less than $10 \%$, and those the Australian krill spp. and Australian pelagic fish spp. groups were less
Fig. 2 Changes in isotope values in $\delta^{13} \mathrm{C}$ (blank square) and $\delta^{15} \mathrm{~N}$ (black circle) along the baleen growth axis, based on the distance from the base of the baleen plates, in pregnant Antarctic minke whales (Balaenoptera bonaerensis)
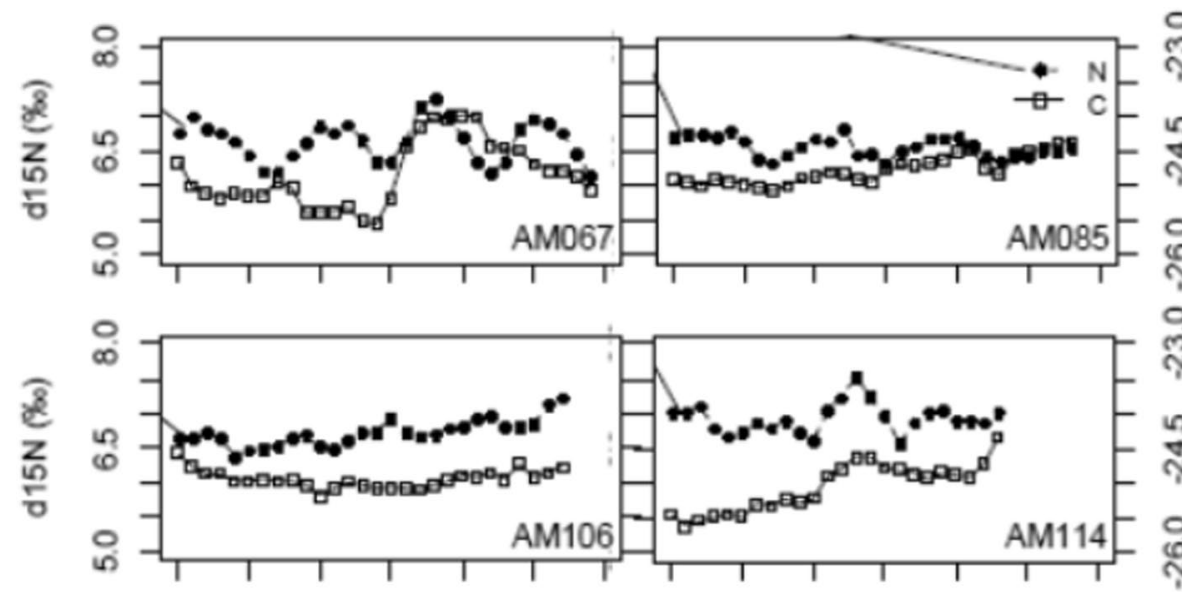

$\frac{2}{\frac{8}{2}}$
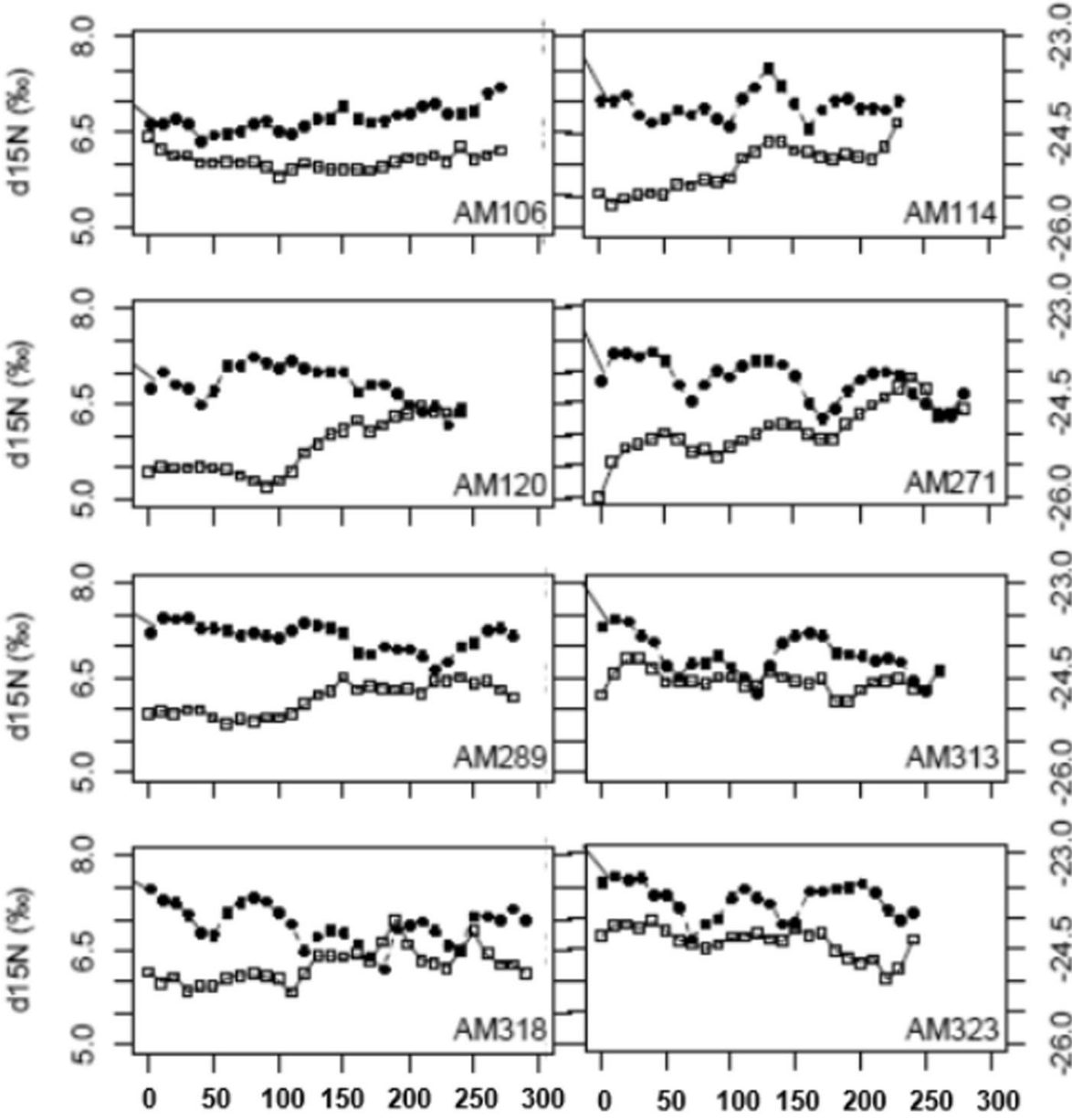

Distance from the base $(\mathrm{mm})$ Distance from the base $(\mathrm{mm})$ 
than $2 \%$ (Table 1). The contribution rates estimated from the points with the highest $\delta^{15} \mathrm{~N}$ values from each baleen plate (Model 2) showed the highest contribution rate of $76.3 \%$ in Antarctic krill. The estimated contribution rate was $11.0 \%$ for Antarctic coastal krill, 8.8\% for Antarctic silver fish, and no more than $2.0 \%$ for the Australian krill spp. and Australian pelagic fish spp. groups (Table 1, Online Resource 2a).

The correlation analysis of the differential stable isotope values between 0 and $10 \mathrm{~mm}$ of each baleen plate and the blubber thickness showed a significant negative correlation between the differential stable isotope values of $\delta^{13} \mathrm{C}$ and blubber thickness $\left(y=-2.4799 \times+4.3536, R^{2}=0.50\right.$, $p=0.038$, Spearman's rank correlation coefficient $=-0.66$; Online Resource $2 b$ ). The correlation between the differential stable isotope values of $\delta^{15} \mathrm{~N}$ and blubber thickness tended to be negative but was not significant $(y=-0.9965$ $\times+4.3024, R^{2}=0.033, p=0.70$, Spearman's rank correlation coefficient $=-0.14$, Online Resource $2 b$ ).

\section{Discussion}

The average stable isotope values at the base of baleen plates $(0 \mathrm{~mm})$ were higher than those of Antarctic krill and Antarctic coastal krill, but lower than those of other prey types (Fig. 1). This indicates that the synthesis of the baleen plates in this study can be made by either Antarctic krill and/or Antarctic coastal krill. The Bayesian stable isotope mixing model showed that Antarctic krill had the highest contribution rate of more than $80 \%$, with the second highest rates (less than 10\%) for Antarctic coastal krill in all the three recent sample points (Model 1: 0, 10, $20 \mathrm{~mm}$ ) (Table 1). These results suggest that the Antarctic minke whales predominantly feed on Antarctic krill in the Southern Ocean. The average annual growth rate of the baleen plates was $75.2 \pm 20.4 \mathrm{~mm}$ in this study, which means that each sample collected at each $10 \mathrm{~mm}$ interval represents a record of 1.6 months. Assuming a constant growth rate during the migration period, our results showed that the stable isotope components of the baleen plates from either October or November 2015 were predominantly from Antarctic krill.

According to the sighting survey from 1976 to 1987, most pregnant females departed their breeding areas by November (Kasamatsu et al. 1995), which indicates that the pregnant females were at the lower latitude around the breeding area in October 2015 and the baleen plates at that time were not synthesized from local prey from the lower latitudes. Fasting behavior during the migration period was confirmed in fin whales with sparse or non-existing prey resources on the northwestern coast of Spain in summer (Aguilar 2008). The stable isotope values of nitrogen in both muscle tissues from the posterior to the dorsal fin and baleen plates decreased during the fasting period (Aguilar et al. 2014). On the other hand, a previous stable isotope study on muscle tissues from bowhead whales indicated increased $\delta^{15} \mathrm{~N}$ values as an effect of the period of fasting (or 'near-fasting') (Lee et al. 2005), while another study on the baleen plates of southern right whales indicated that the period of fasting did not impact stable isotope values (Best and Schell 1996). A clear reason for this physiological discrepancy due to the effect of fasting among these mysticetes cannot be explained here because our study did not have any actual prey samples from whale stomachs at the lower latitude. However, there are some reports of the stomach contents of southern minke whales (Balaenoptera acutorostrata bonaerensis) that were captured at the lower latitudes during the commercial whaling era in Brazil and South Africa. According to these reports, most whales had empty stomachs at the lower latitude, but a little krill was found in the stomach contents from $3 \%$ of whales in Brazil (Williamson 1975), and approximately 10-20\% of whales had some krill and crustaceans from August to September in South Africa (Best 1982). These reports suggest that fasting behavior is not essential for southern minke whales during the migration period.

The results of Model 2 from the Bayesian stable isotope mixing model also showed that the highest contribution rate (76\%) was Antarctic krill and the second highest rate was Antarctic coastal krill (11\%) (Table 1). Even the maximum $\delta^{15} \mathrm{~N}$ values from each baleen plate were lower than the stable isotope values of Antarctic silver fish and the Australian krill spp. and pelagic fishes groups (Fig. 1). The results from both models suggest that the synthesis of the baleen plates of Antarctic minke whales was predominantly dependent on Antarctic krill from the Southern Ocean and may not be dependent on prey from the lower latitude, at least for the stable isotope components of the baleen plates. Reports of the stomach contents of southern minke whales at the lower latitudes during the migration period indicated feeding on local krill and crustaceans occurred, but more than $80 \%$ of the whales had empty stomachs (Williamson 1975; Best 1982). Supplemental feeding on zooplankton during the migration period was also suggested in a previous study (Aguilar et al. 2014), in which migrating fin whales had lipid-dominated catabolism and supplemental feeding on protein-rich zooplankton would be useful for acquiring the basic requirements for protein recycling. To our knowledge, the effect of supplemental feeding on the stable isotope values of the baleen plates is unknown, but our results suggested less than $2 \%$ of the effects of supplemental feeding on groups of Australian krill and Australian pelagic fish during the 3.2 months of records before the whales were captured in the Southern Ocean (Table 1, Online Resource 2a).

The correlation analysis showed a significant relationship between the blubber thickness and the differential stable isotope values of $\delta^{13} \mathrm{C}$ between the most recent and second most recent points $(0 \mathrm{~mm}$ and $10 \mathrm{~mm}$ from the base of 
the baleen plate) (Online Resource $2 b$ ). It was previously proposed that pregnancy in humpback whales has negative effects on both $\delta^{13} \mathrm{C}$ and $\delta^{15} \mathrm{~N}$ due to increased lipid metabolism to support the energetic costs of early pregnancy and a reduction of nitrogen excretion (Clark et al. 2016). Although these theoretical responses were not confirmed in that study due to slightly different sampling periods between the experimental years, our results supported the notion of decreases in $\delta^{13} \mathrm{C}$ as an effect of pregnancy. In this study, the blubber thickness was used as an indicator of pregnancy stages, because thicker blubber suggests longer periods of resumed feeding in the Southern Ocean (Konishi et al. 2008), which also means more developed stages of pregnancy. During pregnancy, the increased energy demand for tissue synthesis in the fetal body is expected to accelerate lipid metabolism, especially during the migration period when the whales have less or no exogenous nitrogen supply, which causes a decrease in $\delta^{13} \mathrm{C}$ because of the isotopic lightness of lipids compared with proteins (Kelly 2000; Kurle and Worthy 2001). On the other hand, there was also a tendency of a negative correlation, which was not statistically significant, between the blubber thickness and the differential $\delta^{15} \mathrm{~N}$ values (Online Resource $2 \mathrm{~b}$ ). A decline in the $\delta^{15} \mathrm{~N}$ values is expected in mammalian females as their body becomes net anabolic and nitrogen excretion decreases (Kalhan 2000; Fuller et al. 2005; Newsome et al. 2010). All pregnant Antarctic minke whales sampled in this study were captured in the Southern Ocean, which means they resumed intensive feeding as the stomach contents showed Antarctic krill, with the exceptions of one individual with damaged stomach (AM085) and another individual with empty stomach (AM289) (Online Resource 1a). Although the timing of when AM289 arrived in the Southern Ocean was not clear because its blubber thickness was not the lowest among the ten individuals, increased $\delta^{15} \mathrm{~N}$ values as a result of intensive feeding were reported in other baleen whales, such as southern right whales (Best and Schell 1996), bowhead whales (Hobson and Schell 1998; Knoche et al. 2007), North Atlantic right whales (Summers et al. 2006), and fin whales (Aguilar et al. 2014). Therefore, a decline in $\delta^{15} \mathrm{~N}$ values due to pregnancy would be confounded by resumed feeding in the Southern Ocean.

The annual growth rate of the baleen plate was estimated from the average length of the periodic cycles observed in the $\delta^{15} \mathrm{~N}$ values in this study. Compared with the cycles in $\delta^{13} \mathrm{C}$, the cycles in $\delta^{15} \mathrm{~N}$ had more periodicity as the average number of cycles was stable ( $2-3$ cycles in each baleen plate), with a narrower range of cycle lengths (50-120 mm) (Fig. 2, Online Resource 1b). Although we expected periodic cycles in both stable isotopes, as found in a previous study where there were periodic cycles in $\delta^{13} \mathrm{C}$ in bowhead whales (Schell et al. 1989), the bowhead whales showed higher amplitude $\left(2-3 \%\right.$ ) oscillations of $\delta^{13} \mathrm{C}$. Feeding at geographically wide ranges across latitudes has been considered to cause wider changes in $\delta^{13} \mathrm{C}$ (Rau et al. 1982; Schell et al. 1989). Therefore, low amplitudes in $\delta^{13} \mathrm{C}$ from our data also support that the pregnant Antarctic minke whales did not actively feed at the lower latitudes, which contributed to the high isotopic composition of Antarctic krill in the baleen plates.

The stable isotope analysis of $\delta^{15} \mathrm{~N}$ and $\delta^{13} \mathrm{C}$ has been applied to the baleen plates of pregnant Antarctic minke whales to understand the growth rate of the baleen plate and identify the prey species foraged outside of the Southern Ocean. The periodic cycle in $\delta^{15} \mathrm{~N}$ showed an average annual baleen growth rate of $75.2 \pm 20.4 \mathrm{~mm}$; thus, a feeding record of 3.7 years can be estimated from the average length of the baleen plate in this species. A comparison of the stable isotope values with potential prey species indicated that only Antarctic krill and Antarctic silver fish were selected as isotopic prey, and the Bayesian stable isotope mixing model suggested that approximately $80 \%$ of the stable isotope components for the synthesis of baleen plates were Antarctic krill during the 3.2 months of the record before the whales were captured. Changes in the stable isotopes due to supplemental feeding on local prey during the migration period were not confirmed from the potential prey species used in this study, while a decline in $\delta^{13} \mathrm{C}$ values due to the effect of pregnancy was supported by our results. This study confirmed that non-active feeding can be detected by the stable isotope analysis of $\delta^{15} \mathrm{~N}$ and $\delta^{13} \mathrm{C}$ in a capital breeder if it migrates geographically wide ranges across latitudes, such as winter breeding at lower latitudes.

Supplementary Information The online version contains supplementary material available at https://doi.org/10.1007/s00300-021-02816-5

Acknowledgements We would like to thank all the captains, crews, and scientists who were involved in the NEWREP-A surveys. The stable isotope analysis was supported by a mechanical assistant by Takahiro Ichise from the Graduate School of Veterinary Medicine, Hokkaido University. The NEWREP-A program was conducted with permission from the Japanese Fisheries Agency, Government of Japan. We would like to thank Editage (www.editage.com) for English language editing.

Author contributions MU, IS, KI, TT, KK, TB, and YM developed concepts; TT, KK, and TB obtained the baleen plates; MU, IS, KI, MI, YI, and SN performed the stable isotope analysis; MU and IS wrote the first draft of the manuscript and IS and YM revised the manuscript. All authors commented on the previous versions of the manuscript and approved the final manuscript.

Funding Financial support to Ippei Suzuki and Yoko Mitani was provided by the Institute of Cetacean Research.

\section{Compliance with ethical standards}

Conflict of interest The authors declare that they have no conflicts of interest. 
Ethical approval This study involved lethal sampling of Antarctic minke whales, which was conducted with the special permit issued by the Government of Japan in accordance with Article VIII of the International Convention for the Regulation of Whaling. The scientific rationale and needs for this lethal sampling are provided in the research program (Government of Japan 2015).

Research involving human and animal rights All whales were sampled under the International Convention for the Regulation of Whaling. No commercial affiliation exists that would influence experimental design, sampling, and data analysis. No funding was received from any commercial sources.

Open Access This article is licensed under a Creative Commons Attribution 4.0 International License, which permits use, sharing, adaptation, distribution and reproduction in any medium or format, as long as you give appropriate credit to the original author(s) and the source, provide a link to the Creative Commons licence, and indicate if changes were made. The images or other third party material in this article are included in the article's Creative Commons licence, unless indicated otherwise in a credit line to the material. If material is not included in the article's Creative Commons licence and your intended use is not permitted by statutory regulation or exceeds the permitted use, you will need to obtain permission directly from the copyright holder. To view a copy of this licence, visit http://creativecommons.org/licenses/by/4.0/.

\section{References}

Aguilar A, Giménez J, Gómez-Campos E, Cardona L, Borrell A (2014) $\delta^{15} \mathrm{~N}$ value does not reflect fasting in Mysticetes. PLoS ONE 9(3):e92288

Aguilar A (2008) Fin whale. In: Perrin WF, Wursig B, Thewissen JG (eds) Encyclopedia of marine mammals, 2nd edn. ElsevierAcademic Press, Amsterdam, pp 433-436

Best PB (1982) Seasonal abundance, feeding, reproduction, age and growth in minke whales off Durban (with incidental observations from the Antarctic). Rep Int Whal Comm 32:759-786

Best PB, Schell DM (1996) Stable isotopes in southern right whale (Eubalaena australis) baleen as indicators of seasonal movements, feeding and growth. Mar Biol 124:483-494

Borrell A, Abad-Oliva N, Gómez-Campos E, Giménez J, Aguilar A (2012) Discrimination of stable isotopes in fin whale tissues and application to diet assessment in ceraceans. Rapid Commun Mass Spectrom 26:1596-1602

Clark CT, Fleming AH, Calambokidis J, Kellar NM, Allen CD, Catelani KN, Robbins M, Beaulieu NE, Steel D, Harvey JT (2016) Heavy with child? Pregnancy status and stable isotope ratios as determined from biopsies of humpback whales. Conserv Physiol 4(1):1-13

Davenport SR, Bax NJ (2002) A trophic study of a marine ecosystem off Southeastern Australia using stable isotopes of carbon and nitrogen. Can J Fish Aquat Sci 59(3):514-530

Eisenmann P, Fry B, Holyoake C, Coughran D, Nicol S, Bengtson Nash $S$ (2016) Isotopic evidence of a wide spectrum of feeding strategies in Southern Hemisphere Humpback whale baleen records. PLoS ONE 11(5):e0156698

Fuller BT, Fuller JL, Sage NE, Harris DA, O'Connell TC et al (2005) Nitrogen balance and $\delta^{15} \mathrm{~N}$ : why you're not what you eat during nutritional stress. Rapid Commun Mass Spectrom 19:2497-2506

Government of Japan (2015) Research Plan for New Scientific Whale Research Program in the Antarctic Ocean (NEWREP-A). IWC. ALL. 238, November 2015, p 110
Harris BP, Young JW, Revill AT, Taylor MD (2014) Understanding diel-vertical feeding migrations in zooplankton using bulk carbon and nitrogen stable isotopes. J Plankton Res 36(4):1159-1163

Hobson KA, Schell DM (1998) Stable carbon and nitrogen isotope patterns in baleen from eastern Arctic bowhead whales (Balaena mysticetus). Can J Fish Aquat Sci 55:2601-2607

Hobson KA, Alisauskas RT, Clark RG (1993) Stable-nitrogen isotope enrichment in avian tissues due to fasting and nutritional stress: implications for isotopic analyses of diet. Condor 95:388-394

Hodum PJ, Hobson KA (2000) Trophic relationships among Antarctic fulmarine petrels; insights into dietary overlap and chick provisioning strategies inferred from stable-isotope $\left(\delta^{15} \mathrm{~N}\right.$ and $\left.\delta^{13} \mathrm{C}\right)$ analyses. Mar Ecol Prog Ser 198:273-281

Ichii T, Kato H (1991) Food and daily food consumption of southern minke whales in the Antarctic. Pol Biol 11:479-487

Kalhan SC (2000) Protein metabolism in pregnancy. Am J Clin Nutr 71:1249-1255

Kasamatsu F, Nishiwaki S, Ishikawa H (1995) Breeding areas and southbound migrations of southern minke whales Balaenoptera acutorpstrata. Mar Ecol Prog Ser 119:1-10

Kato H (1990) Life cycles of baleen whales especially minke whales in southern hemisphere. In: Miyazaki N, Kasuya T (eds) Biology of marine mammals. Scientist-Sha press, Tokyo, pp 128-150 (in Japanese)

Kelly JF (2000) Stable isotopes of carbon and nitrogen in the study of avian and mammalian trophic ecology. Can J Zool 78:1-27

Knoche M, Suydam RS, George JC, Morita J (2007) Using stable isotopes in baleen to examine migratory behavior of BeringChukchi-Beaufort Sea bowhead whales (Balaena mysticetus): a pilot study. International Whaling Comission. Scientic committee: SC/59/BRG13

Konishi K, Tamura T, Zenitani R, Bando T, Kato H, Walløe L (2008) Decline in energy storage in the Antarctic minke whale (Balaenoptera bonaerensis) in the Southern Ocean. Pol Biol 31:1509-1520

Kurle CM, Worthy GAJ (2001) Stable isotope assessment of temporal and geographic differences in feeding ecology of northern fur seals (Callorhinus ursinus) and their prey. Oecologia 126(2):254-265

Lee SH, Schell DM, McDonald TL, Richardson WJ (2005) Regional and seasonal feeding by bowhead whales Balaena mysticetus as indicated by stable isotope ratios. Mar Ecol Prog Ser 285:271-287

Lockyer C (1984) Review of baleen whale (Mysticeti) reproduction and implications for management. Rep Int Whal Comm 6:27-50

Mitani Y, Bando T, Takai N, Sakamoto W (2006) Patterns of stable carbon and nitrogen isotopes in the baleen of common minke whale (Balaenoptera acutorostrata) from the western North Pacific. Fish Sci 72:69-76

Newsome SD, Clementz MT, Koch PL (2010) Using stable isotope biogeochemistry to study marine mammal ecology. Mar Mammal Sci 26:509-572

Ohsumi S (1973) Find of a marlin spear from the Antarctic minke whales. Sci Rep Whales Res Inst 25:237-239

Ohsumi S, Masaki Y (1975) Biological parameters of the Antarctic minke whale at the virgin population level. J Fish Res Board Can 32(7):995-1004

Parnell AC, Inger R, Bearhop S, Jackson AL (2010) Source partitioning using stable isotopes: coping with too much variation. PLoS ONE 5(3):e9672. https://doi.org/10.1371/journal.pone.0009672

Pinkerton MH, Forman J, Bury SJ, Brown J, Horn P, O’Driscoll RL (2013) Diet and trophic niche of Antarctic silverfish Pleuragramma antarcticum in the Ross Sea, Antarctica. J Fish Biol $82: 141-164$

Polischuck SC, Hobson KA, Ramsay MA (2001) Use of stable carbon and nitrogen isotopes to assess weaning and fasting in female polar bears and their cubs. Can J Zool 79:499-511 
Rau GH, Sweeney RE, Kaplan IR (1982) Plankton ${ }^{13} \mathrm{C}:{ }^{12} \mathrm{C}$ ratio changes with latitude: differences between northern and southern oceans. Deep-Sea Res 29(8A):1035-1039

Reiss L, Häussermann V, Mayr C (2020) Stable isotope records of sei whale baleens from Chilean Patagonia as archives for feeding and migration behavior. Ecol Evol 10:808-818

Schell DM, Saupe SM, Haubenstock N (1989) Bowhead whale (Balaena mysticetus) growth and feeding as estimated by $\delta^{13} \mathrm{C}$ techniques. Mar Biol 103:433-443

Summers EL, Estrada JA, Zeeman SI (2006) A note on geographical and seasonal fluctuations in the isotopic composition of baleen in four North Atlantic right whales (Eubalaena glacialis). J Cetacean Res Manag 8:241-245
Tamura T, Konishi K (2009) Feeding habits and prey consumption of Antarctic minke whale (Balaenoptera bonaerensis) in the Southern Ocean. J Northw Atl Fish Sci 42:13-25

Williamson GR (1975) Minke whales off Brazil. Sci Rep Whales Res Inst 27:37-59

Publisher's Note Springer Nature remains neutral with regard to jurisdictional claims in published maps and institutional affiliations. 